\title{
Pengaruh Kompetensi dan Motivasi Terhadap Kinerja Karyawan Pada PT. Putra Fajar Jaya, Medan
}

\author{
Oleh : \\ Syaifuddin* \\ Program Studi Manajemen Universitas Quality \\ *Email:drsyaifuddin@gmail.com
}

\begin{abstract}
Abstrak
Tujuan penelitian ini adalah untuk mengetahui pengaruh kompetensi dan motivasi terhadap kinerja karyawan pada PT. Putra Fajar Jaya, Medan. Penelitian ini dilaksanakan pada PT. Putra Fajar Jaya yang berlamat di Kompleks Villa Asoka Blok C No. 6, Medan. Penelitian ini dilakukan pada bulan Maret 2017. Sampel yang diambil dalam penelitian ini adalah karyawan PT. Putra Fajar Jaya, Medan sebanyak 30 orang. Metode pengumpulan data menggunakan kuesioner pada setiap variabel penelitian yaitu kompetensi, motivasi dan kinerja karyawan. Analisis data dilakukan dengan uji regresi linier berganda. Hasil penelitian menunjukkan bahwa kompetensi dan motivasi kerja secara simultan mempunyai pengaruh yang signifikan terhadap kinerja karyawan. Hasil pengujian secara parsial menunjukkan bahwa kompetensi dan motivasi kerja memiliki pengaruh secara signifikan terhadap kinerja karyawan. Faktor motivasi mempunyai pengaruh yang lebih dominan terhadap kinerja karyawan dibandingkan dengan kompetensi.
\end{abstract}

\section{Kata kunci : kompetensi; motivasi; kinerja}

\begin{abstract}
The purpose of this research is to know about the influence competency and motivation on employee performance. The paper provides the analysis result about influence of the competency and motivation on employee performance at PT Putra Fajar Jaya, addressed in Kompleks Villa Asoka Blok C No. 6, Medan. Theresearch has been done on March 2017. Samples that have been taken are 30 people. The research uses data collection methods using questionnaires on each variable, which are competency, motivation and employee performance. Data analysis was done by multiple linier regression test. The result show that competency and work motivation simultaneously have a significant effect on employee performance. Partial test result show that competency and work motivation have a significant effect on employee performance. Motivational factors have more influence on employee performance compared with competency.
\end{abstract}

Keyword: Competency; Motivation; Performance. 


\section{PENDAHULUAN}

Kinerja (performance) adalah gambaran mengenai tingkat pencapaian pelaksanaan suatu kegiatan/program/kebijakan dalam mewujudkan sasaran, tujuan, misi dan visi organisasi yang tertuang dalam perencanaan strategis suatu organisasi. Istilah kinerja sering digunakan untuk menyebut prestasi atau tingkat keberhasilan individu maupun kelompok. Kinerja bisa diketahui hanya jika individu atau kelompok tersebut mempunyai kriteria keberhasilan yang telah ditetapkan sebelumnya. Kriteria keberhasilan ini berupa tujuan-tujuan atau target-target tertentu yang hendak dicapai. Tanpa ada tujuan atau target, kinerja seseorang atau organisasi tidak mungkin dapat diketahui karena tidak ada tolak ukurnya.

Strategi sumber daya manusia juga menyangkut masalah kompetensi dalam kemampuan teknis, konseptual, dan hubungan manusia. Pengelolaan kompetensi tenaga kerja meliputi beberapa kompetensi seperti: kompetensi berbasis input, kompetensi transformasional, kompetensi output.

Pengaruh kompetensi pada kinerja dapat dilihat dari tingkat kompetensinya yang mempunyai implikasi praktis dalam perencanaan sumber daya manusia, hal ini dapat dilihat dari gambaran bahwa kompetensi pengetahuan dan keahlian cenderung lebih nyata dan relatif lebih ada dipermukaan salah satu karakteristik yang dimiliki karyawan.

Tujuan yang mulia pada saat ini tampaknya sulit tercapai apabila organisasi yang karyawannya tidak bersemangat dalam menjalankan tugas yang dibebankan kepadanya. Setiap organisasi bukan saja mengharapkan karywan yang mampu, cakap, dan trampil, tetapi tidak kalah penting karyawan mau bekerja giat dan berkeinginan untuk mencapai hasil yang maksimal. Kemampuan dan kecakapan tidak ada artinya bagi organisasi jika mereka tidak mau bekerja giat. Tujuan pegelolaan sistem kompensasi didalam organisasi adalah untuk menarik dan mempertahankan sumber daya manusia karena organisasi memerlukannya untuk mencapai sasaran-sasarannya. Agar organisasi dapat berkembang luas dengan segala kegiatan-kegiatan yang dilakukan untuk mencapai tujuan yang diinginkan dengan menggunakan sumber daya manusia yang telah tersedia, tetapi untuk mencapai tujuan tersebut, tidak cukup hanya dengan jalan memperoleh karyawan yang dianggap paling kompeten, akan tetapi tidak kalah pentingnya dengan secara terus menerus pimpinan memberikan motivasi dan Kompensasi kepada karyawan agar lebih bersemangat dalam menjalankan tugas-tugasnya di organisasi. Kompetensi karyawan dipengaruhi oleh tingkat pendidikannya. Kompetensi berpengaruh terhadap kinerja pegawai. Seorang karyawan yang memiliki kompetensi yang tinggi seperti pengetahuan, ketrampilan, kemampuan, dan sikap yang sesuai dengan jabatan yang diembannya selalu terdorong untuk bekerja secara efektif, efesien dan produktif. Hal ini terjadi karena dengan kompetensi yang dimiliki karyawan bersangkutan semakin mampu untuk 
melaksanakan tugas-tugas yang dibebankan kepadanya.

Motivasi kerja mempunyai peranan yang penting dalam hal penumbuhan gairah, merasa senang dan semangat untuk bekerja secara optimal. Karyawan yang memiliki motivasi kerja yang kuat akan mempunyai banyak energi untuk melakukan kegiatan. Seorang karyawan yang memiliki intelegensia cukup tinggi bisa gagal karena kekurangan motivasi.

PT. Putra Fajar Jaya Medan merupakan salah satu perusahaan yang bergerak di bidang perumahan. Maka untuk menjamin terlaksananya tugastugas yang diembannya yang pada gilirannya adalah kinerja karyawannya memadai sangat diperlukan Sumber Daya Manusia (SDM) yang berkompeten dan motivasi yang tinggi dari ke atasan ataupun bawahan yang harmonis, terlebih dengan warga masyarakat yang membutuhkan layanan.

Penurunan motivasi dan produktivitas kerja karyawan juga tercermin dari rendahnya tingkat kedisiplinan dari beberapa karyawan terhadap peraturan dan kebijaksanaan perusahaan serta minimnya partisipasi dari tiap karyawan untuk memajukan organisasi. Ditambah lagi dengan permasalahan seputar motivasi kerja internal yang belum efektif, adanya kerancuan pada deskripsi kerja dan kekurangakuratan dalam evaluasi kerja yang dilakukan oleh sebagian penilai dapat semakin memicu lemahnya motivasi kerja yang sudah dimiliki oleh para karyawan tersebut. Penelitian ini bertujuan untuk mengetahui pengaruh kompetensi dan motivasi terhadap kinerja karyawan pada PT. Putra Fajar
Jaya, Medan.

\section{METODE PENELITIAN}

Penelitian ini dilaksanakan pada PT. Putra Fajar Jaya yang beralamat di Kompleks Villa Asoka Blok C No. 6, Medan. Penelitian ini dilakukan pada bulan Maret 2017. Sampel yang diambil dalam penelitian ini adalah karyawan PT. Putra Fajar Jaya, Medan yang berasal dari berbagai sub bagian yaitu : SDM, keuangan dan personalia. Penentuan jumlah sampel dalam penelitian ini menggunakan rumus Slovin (Umar, 2013 : 42) yang dituliskan sebagai berikut:

$$
\mathrm{n}=\frac{\mathrm{N}}{1+\mathrm{N}[\mathrm{e}]^{2}}
$$

Dimana: $\mathrm{n}=$ Jumlah sampel

$$
\begin{aligned}
& \mathrm{N}=\text { Jumlah Populasi sampel } \\
& \mathrm{e}=\text { Jumlah kesalahan dalam }
\end{aligned}
$$
pengambilan sampel (error term).

Mengacu pada rumus tersebut, maka jumlah sampel dalam penelitian ini sebanyak

$$
\begin{aligned}
& \mathrm{n}=\frac{78}{1+\left(78 \times(0,15)^{2}\right)} \\
& \mathrm{n}=\frac{78}{1+1,76}
\end{aligned}
$$

$\mathrm{n}=28,31$ (dibulatkan menjadi 30).

Maka jumlah sampel yang digunakan dalam penelitian ini sebanyak 30 responden.

Selanjutnya untuk mengetahui pengaruh kompetensi dan motivasi terhadap kinerja karyawan dilakukan dengan uji regresi linier berganda yang didukung dengan program SPSS versi 19 for windows. Adapun rumus Regression Analysis adalah sebagai berikut:

$$
\mathrm{Y}=\mathrm{a}+\mathrm{b}_{1} \mathrm{X}_{1}+\mathrm{b}_{2} \mathrm{X}_{2}+\mathrm{ei}
$$

Keterangan :

Y : Variabel kinerja karyawan 
$\mathrm{b}_{1}$ : Koefisien regresi kompetensi

$b_{2}$ : Koefisien regresi motivasi kerja

$\mathrm{X}_{1}$ : Kompetensi

$\mathrm{X}_{2}$ : Motivasi kerja

a : Bilangan konstan

ei : Variabel gangguan

HASIL DAN PEMBAHASAN

Pengujian regresi linear berganda menjelaskan besarnya peranan kompetensi dan motivasi kerja terhadap kinerja karyawan. Analisis data dalam penelitian ini menggunakan analisis regresi linier berganda dengan menggunakan SPSS 19.0 for windows. Analisis masing-masing variabel dijelaskan dalam uraian berikut :

\section{Tabel 1. Hasil Regresi Linier Berganda}

Coefficients $^{\mathbf{a}}$

\begin{tabular}{|ll|c|c|c|c|c|}
\hline \multirow{2}{*}{ Model } & \multicolumn{2}{|c|}{$\begin{array}{c}\text { Unstandardized } \\
\text { Coefficients }\end{array}$} & \multicolumn{2}{c|}{$\begin{array}{c}\text { Standardized } \\
\text { Coefficients }\end{array}$} & \multirow{2}{*}{$\mathrm{t}$} & Sig. \\
\cline { 3 - 4 } & $\mathrm{B}$ & Std. Error & Beta & & \\
\hline 1 & (Constant) & -.512 & 3.451 & & -.148 & .883 \\
& Kompensasi & .264 & .125 & .284 & 2.110 & .044 \\
& Motivasi & .678 & .144 & .636 & 4.110 & .000 \\
\hline
\end{tabular}

a. Dependent Variable : Kinerja

Berdasarkan hasil tersebut maka persamaan regresi linier berganda yang mempunyai formulasi : $\mathrm{Y}=\mathrm{b}_{0}+\mathrm{b}_{1} \mathrm{X}_{1}+$ $\mathrm{b}_{2} \mathrm{X}_{2}+\varepsilon$, sehingga diperoleh persamaan : $Y=-0,512+0,264 X_{1}+0,678 X_{2}$ dengan estimasi simpangan baku peramalan sebesar 3,786.

Deskripsi dari persamaan regresi linear berganda di atas adalah sebagai berikut :

$b_{0}:-0,512$

Bilangan konstanta $\left(b_{0}\right)$ sebesar 0,512 menunjukkan besarnya kinerja karyawan apabila kompetensi dan motivasi kerja sama dengan 0 .

$b_{1}: 0,264$

Koefisien regresi pertama $\left(b_{1}\right)$ sebesar 0,264 menunjukkan besarnya peranan kompetensi terhadap kinerja karyawan dengan asumsi motivasi kerja konstan. Artinya apabila faktor kompetensi meningkat 1 satuan nilai, maka diprediksi kinerja karyawan meningkat sebesar 0,264 satuan nilai dengan asumsi motivasi kerja konstan.

$b_{2}: 0,678$

Koefisien regresi kedua $\left(b_{2}\right)$ sebesar 0,678 menunjukkan besarnya peranan motivasi kerja terhadap kinerja karyawan dengan asumsi kompetensi konstan. Artinya apabila faktor motivasi kerja meningkat 1 satuan nilai, maka diprediksi kinerja karyawan meningkat sebesar 0,678 satuan nilai dengan asumsi kompetensi konstan.

Untuk mengetahui pengaruh kompetensi dan motivasi seara simultan dilakukan uji F. Uji ini bertujuan untuk menguji signifikannya peranan kompetensi dan motivasi kerja secara simultan terhadap kinerja karyawan. Hasil uji $\mathrm{F}$ dapat dilihat pada Tabel 2. 
Tabel 2. Uji F

ANOVA $^{b}$

\begin{tabular}{|ll|c|c|c|c|c|}
\hline & Model & Sum of Squares & df & Mean Square & F & Sig. \\
\hline 1. & Regression & 1016.465 & 2 & 508.233 & 35.455 & $.000^{\mathrm{a}}$ \\
& Residual & 387.035 & 27 & 14.335 & & \\
Total & 1403.500 & 29 & & & \\
\hline
\end{tabular}

a. Predictors : (Constant), Motivasi, Kompensasi

b. Dependent Variable : Kinerja

Berdasarkan uji F dapat diketahui bahwa secara simultan kompetensi dan motivasi berpengaruh signifikan terhadap kinerja karyawan dengan nilai F-hitung sebesar 35,455 dengan tingkat signifikansi sebesar $0,000<0,05$.

Berdasarkan analisis koefisien determinasi parsial di atas diketahui bahwa pengaruh kompetensi lebih besar dibandingkan dengan motivasi kerja terhadap kinerja karyawan, oleh karena itu untuk menguji kebenarannya digunakan uji hipotesis parsial atau uji-t. Dalam penelitian ini, uji hipotesis parsial dilakukan pada setiap variabel indepenen seperti pada Tabel 3 .

\section{Tabel 3. Uji Parsial (t) Variabel Bebas}

\begin{tabular}{|c|c|c|c|c|c|c|c|c|c|}
\hline \multicolumn{10}{|c|}{ Coefficients $^{a}$} \\
\hline \multirow{2}{*}{\multicolumn{2}{|c|}{ Model }} & \multicolumn{2}{|c|}{$\begin{array}{l}\text { Unstandardized } \\
\text { Coefficients }\end{array}$} & \multirow{2}{*}{$\begin{array}{c}\text { Standartized } \\
\text { Coefficients }\end{array}$} & \multirow[t]{2}{*}{$\mathrm{T}$} & \multirow[t]{2}{*}{ Sig. } & \multicolumn{3}{|c|}{ Correlations } \\
\hline & & $\mathrm{B}$ & Std. Error & & & & Zero-Order & Partial & Part \\
\hline \multirow[t]{3}{*}{1} & (Constant) & -.512 & 3.451 & & -.148 & .883 & & & \\
\hline & Kompetensi & .264 & .125 & .284 & 2.110 & .044 & .705 & .376 & .213 \\
\hline & Motivasi & .678 & .144 & .636 & 4.720 & .000 & .824 & .672 & .477 \\
\hline
\end{tabular}

a. Dependent Varible : Kinerja

1). Uji hipotesis peran kompetensi terhadap kinerja karyawan.

Prosedur dan kriteria penerimaan serta penolakan hipotesis ditetapkan sebagai berikut:

a. Hipotesis

$\mathrm{H}_{0}: \mathrm{b}_{1}=0$ artinya, kompetensi tidak berperan dalam meningkatkan kinerja karyawan.

$\mathrm{H}_{1}: \mathrm{b}_{1} \neq 0$ artinya, kompetensi berperan dalam meningkatkan kinerja karyawan.

b. Uji Hipotesis

Bila tingkat signifikansi thitung < 0,05, maka $\mathrm{H}_{0}$ ditolak artinya kompetensi berperan secara signifikan meningkatkan kinerja karyawan dan apabila tingkat signifikansi thitung $>0,05$, maka $\mathrm{H}_{0}$ diterima, artinya kompetensi tidak mempunyai pengaruh yang signifikan terhadap kinerja karyawan.

c. Berdasarkan hasil pengolahan dengan program SPSS diketahui thitung sebesar 2,110.

d. Dari hasil uji $t$ diperoleh nilai signifikansi kompetensi sebesar $0,044<0,05$. Dari uraian tersebut dapat diketahui bahwa nilai signifikansi thitung $(0,044)<0,05$, maka dapat disimpulkan $\mathrm{H}_{1}$ diterima, artinya kompetensi 
berperan secara signifikan terhadap kinerja karyawan.

2). Uji hipotesis pengaruh motivasi kerja terhadap kinerja karyawan.

Prosedur dan kriteria penerimaan serta penolakan hipotesis ditetapkan sebagai berikut

a. Hipotesis

$\mathrm{H}_{0}: \mathrm{b}_{1}=0$ artinya, motivasi kerja tidak mempunyai pengaruh meningkatkan kinerja karyawan.

$\mathrm{H}_{1}: \mathrm{b}_{1} \neq 0$ artinya, motivasi kerja mempunyai pengaruh meningkatkan kinerja karyawan.

b. Uji Hipotesis

Bila nilai signifikan thitung $<0,05$, maka $\mathrm{H}_{0}$ ditolak artinya motivasi kerja mempunyai pengaruh signifikan meningkatkan kinerja karyawan dan apabila nilai signifikan thitung $>0,05$, maka $\mathrm{H}_{0}$ diterima, artinya motivasi kerja tidak mempunyai pengaruh signifikan meningkatkan kinerja karyawan.

c. Berdasarkan hasil pengolahan dengan program SPSS diketahui thitung sebesar 4,720.

d. Dengan $\alpha=5 \%$, diperoleh nilai sinfikansi tabel sebesar 0,000. Dari uraian tersebut dapat diketahui bahwa nilai signifikansi thitung $(0,000)<0,005$, maka dapat disimpulkan $\mathrm{H}_{1}$ diterima, artinya motivasi kerja memiliki pengaruh signifikan meningkatkan kinerja karyawan.

Berdasarkan hasil penelitian di atas maka dapat diketahui bahwa kompetensi dan motivasi kerja mempunyai pengaruh yang signifikan meningkatkan kinerja karyawan, dimana faktor kompetensi mempunyai pengaruh yang lebih dominan terhadap kinerja karyawan, dibandingkan dengan motivasi kerja.

Koefisien deteriminasi parsial digunakan untuk mengetahui sumbangan kompetensi dan motivasi kerja terhadap naik turunnya kinerja karyawan, sehingga akan diketahui salah satu variabel yang dominan.

Berdasarkan hasil perhitungan dengan program SPSS, maka masingmasing koefisien determinasi parsial dapat dideskripsikan sebagai berikut :

$$
\mathrm{r}^{2}{ }_{1}=0,376
$$

Koefisien determinasi parsial sebesar 0,376 menunjukkan bahwa pengaruh kompetensi terhadap peningkatan kinerja karyawan adalah $37,60 \%$ dan sisanya sebesar $62,40 \%$ dipengaruhi oleh faktor di luar kompetensi.

$$
r^{2}{ }_{2}=0,672
$$

Koefisien determinasi parsial sebesar 0,672 menunjukkan bahwa pengaruh motivasi kerja terhadap peningkatan kinerja karyawan adalah $67,20 \%$ dan sisanya sebesar 32,80\% adalah dipengaruhi oleh faktor di luar motivasi kerja.

Dari kedua besaran koefisien deterimnasi parsial tersebut di atas, diketahui bahwa motivasi kerja $(67,20$ $\%$ lebih dominan berperan meningkatkan kinerja karyawan dibandingkan faktor kompetensi 337,60 $\%)$.

Nilai yang dipergunakan dalam melihat koefisien determinasi dalam penelitian ini adalah pada kolom adjusted $R$ square. Hal tersebut dikarenakan nilai adjusted $R$ square tidak rentan pada penambahan variabel bebas. Nilai koefisien determinasi dapat 
dilihat pada Tabel 4.

\section{Tabel 4. Nilai Koefisien Determinasi}

\begin{tabular}{|c|c|c|c|c|}
\hline $\begin{array}{c}\text { Mod } \\
\text { el }\end{array}$ & $\mathrm{R}$ & $\begin{array}{c}\mathrm{R} \\
\text { Squar } \\
\mathrm{e}\end{array}$ & $\begin{array}{c}\text { Adjuste } \\
\mathrm{d} \mathrm{R} \\
\text { Square }\end{array}$ & $\begin{array}{c}\text { Std. } \\
\text { Error of } \\
\text { the } \\
\text { Estimate }\end{array}$ \\
\hline 1 & .851 & .724 & .704 & 3.78611 \\
\hline
\end{tabular}

a. Predictors : (Cosntant), Motivasi, Kompetensi

Besarnya nilai pengaruh tersebut ditunjukkan oleh nilai koefisien adjusted $\mathrm{R}$ square sebesar 0,724 atau $72,40 \%$ yaitu persentase pengaruh kompetensi $\left(\mathrm{X}_{1}\right)$ dan motivasi kerja $\left(\mathrm{X}_{2}\right)$ terhadap kinerja karyawan (Y) adalah sebesar $72,40 \%$. Sedangkan sisanya sebesar $37,60 \%(100 \%-72,40 \%)$ dipengaruhi oleh variabel lain di luar model penelitian ini.

\section{a. Pengaruh Kompetensi terhadap Kinerja Karyawan \\ Hasil uji t menunjukkan bahwa} kompetensi berpengaruh signifikan terhadap kinerja karyawan. Kompetensi mengacu pada karakter knowledge, skill, dan abilities setiap individu atau karakter personal yang mempengaruhi job performance individu secara langsung. Kompetensi adalah karakteristik mendasar dari individu yang berhubungan dengan ukuran atau referensi efektif atau tidaknya kinerja dalam suatu pekerjaan atau situasi tertentu. Kompetensi dapat digunakan untuk memprediksi kinerja, yaitu siapa yang berkinerja baik dan kurang baik tergantung pada kompetensi yang dimilikinya, diukur dari kriteria atau standar yang digunakan. Hal ini menunjukkan bahwa kompetensi akan meningkatkan motivasi yang selanjutnya berpengaruh meningaktkan kinerja.
Karyawan profesional harus memiliki kemampuan menguasai bidang pekerjaan. Kompetensi seorang karyawan adalah kemampuan karyawan dalam melaksanakan pekerjaannya secara tepat. Dalam hal ini, kompetensi kayawan akan berdampak terhadap kinerja karyawan dan akan memberikan kontribusi terhadap kualitas pekerjaannya. Kinerja karyawan akan memberikan dampak yang besar terhadap pelaksanaan pekerjaannya secara efektif. Menurut Palan (2007 : 57) bahwa kompetensi merujuk kepada karakteristik yang mendasari perilaku yang menggambarkan motif, karakteristik pribadi, konsep diri/nilainilai, pengetahuan dan keahlian yang dibawa seseorang yang berkinerja unggul (superior performer) di tempat kerja.

b. Pengaruh Motivasi Kerja terhadap Kinerja Karyawan

Hasil uji t menunjukkan bahwa kompetensi berpengaruh positif dan signifikan terhadap kinerja karyawan. Motivasi merupakan salah satu faktor yang memberikan kontribusi terhadap kinerja karyawan. Dengan adanya motivasi yang tinggi berarti pula karyawan tersebut mempunyai minat yang tinggi dalam menjalankan rutinitas kerja sesuai dengan apa yang menjadi tanggung jawabnya. Dengan adanya minat yang tinggi, karyawan akan bekerja dengan perasaan senang. Perasaaan senang inilah yang mampu memberikan kontribusi terhadap efisiensi dan kinerja karyawan. Motivasi yang tinggi ditunjukkan dari sikap positif karyawan terhadap pekerjaan. Apabila target yang diharapkan 
organisasi terpenuhi, karyawan tersebut merasa senang. Sikap positif lainnya adalah merasa memiliki dan mempunyai frekuensi kehadiran yang tinggi. Sikap tersebut memberikan kontribusi yang berarti terhadap kinerja karyawan.

Motivasi bepengaruh signifikan meningkatkan kinerja karyawan. Karyawan yang memiliki motivasi tinggi dalam bekerja akan memberikan kinerja kerja yang baik, sedangkan bagi karyawan yang memiliki motivasi yang rendah tidak akan memberikan kinerja sebaik karyawan yang memiliki motivasi yang tinggi. Semua itu tercermin melalui sikap karyawan dalam menghadapi pekerjaannya, antara lain ditandai dengan turunnya semangat kerja, cepat merasa bosan, sering absen, terlambat datang dan sebagainya yang pada akhirnya semua berdampak pada penurunan produktivitas karyawan. Menurut Danim (2004 : 140) menyatakan bahwa motivasi rendah akan merugikan produktivitas kelompok. Perilaku anggota yang hanya ingin memenuhi kebutuhan atau kepentingan diri sendiri akan mengurangi rasa kepuasan anggota lainnya, karena itu akan timbul konflik. Dengan demikian, dapat dikatakan bahwa terdapat hubungan negatif antra produktivitas dengan keinginan mementingkan diri sendiri. Susana kerja adalah salah satu faktor penentu produktivitas kelompok. Dengan adanya pemberian motivator yang efektif diharapkan perilaku sumber daya manusia yang mengacu pada peningkatan produktivitas tenaga kerja bisa dibentuk. Oleh karena itu, motivasi kerja menjadi subjek yang sangat penting karena secara fungsional dianggap mempunyai kaitan dengan produktivitas sumber daya manusia melalui peningkatan kinerja.

Motivasi pada suatu organisasi bertujuan untuk mendorong semangat kerja para karyawan agar mau bekerja keras dengan memberikan semua kemampuan dan ketrampilan demi terwujudnya tujuan suatu organisasi. Pimpinan yang mengarahkan karyawannya dengan memberikan motivasi kerja akan menciptakan kondisi dimana karyawan merasa mendapat inspirasi untuk bekerja keras. Karyawan yang mempunyai motivasi tinggi merupakan salah satu syarat jika hasil-hasil kinerja yang tinggi ingin dicapai secara konsisten. Hal ini sejalan dengan dengan pendapat Vroom (dalam Mangkunegara, 2005:51) bahwa motivasi adalah faktor utama membangun kinerja, untuk itu penerapan upah/gaji yang dikaitkan dengan kinerja individu akan dapat lebih meningkatkan motivasi, sekaligus mengisi faktor kesempatan untuk meningkatkan kinerja.

c. Pengaruh Kompetensi dan Motivasi Kerja terhadap Kinerja Karyawan

Hasil uji $\mathrm{F}$ menunjukkan bahwa komptensi dan motivasi kerja berpengaruh signifikan terhadap kinerja karyawan. Hal ini berarti bahwa secara serempak kompetensi dan motivasi kerja berpengaruh signifikan terhadap kinerja karyawan. Karyawan yang berkompeten memiliki tingkat profesionalitas yang cukup tinggi dalam melaksanakan pekerjaannya dengan melakukan pekerjaan dengan cepat dan tepat waktu. Hal ini akan semakin didukung oleh adanya motivasi yang 
diberikan oleh perusahaan kepada karyawannya. Adanya motivasi tertentu kepada karyawan akan semakin memacu semangat karyawan untuk meningkatkan kinerjanya. Motivasi yang diberikan merupakan faktor yang dapat membangun kinerja karyawan. Pemberian motivasi tergantung pada perusahaan, biasanya perusahaan memberikan motivasi dalam bentuk penghargaan dan pemberian insentif kepada karyawan yang memiliki kinerja tinggi.

\section{SIMPULAN}

Hasil penelitian menunjukkan bahwa kompetensi dan motivasi kerja secara simultan mempunyai pengaruh $72,40 \%$ terhadap kinerja karyawan, dimana secara parsial menunjukkan bahwa kompetensi mempunyai pengaruh $37,60 \%$ dan motivasi $67,20 \%$ terhadap kinerja karyawan. Faktor motivasi mempunyai pengaruh yang lebih dominan terhadap kinerja karyawan dibandingkan dengan kompetensi.

\section{DAFTAR PUSTAKA}

Danim Sudarwan, 2004. Motivasi Kepemimpinan dan Efektivitas Kelompok. Jakarta: Rineka Cipta.

Gary Dessler, 2010. Manajemen Sumberdaya Manusia. Edisi Keempatbelas. Klaten : PT. Intansejati.

Gibson, Ivancevich dan Donnelly, 2003. Organisasi: Perilaku, Struktur dan Proses. Jakarta: Erlangga.
Mangkunegara, A.A.Anwar Prabu, 2005. Evaluasi Kinerja Sumber Daya. Bandung: PT Refika Aditama.

Mangkuprawira, Sjafri, 2009. Bisnis, manajemen, dan Sumberdaya Manusia. Jakarta : PT. Gramedia.

Mathis, R.L. dan J.H. Jackson. 2002. Manajemen Sumber Daya Manusia. Jakarta : Salemba Empat.

Notoatmodjo, Soekidjo. 2003. Pendidikan Dan Perilaku Kesehatan. Jakarta : Rineka. Cipta.

Palan, R. 2007. Competency Management : Teknis Mengimplementasikan Manajemen SDM Berbasis Kompetensi untuk Meningkatkan Daya Saing Organisasi. Jakarta : PPM.

Rivai, Veitzhal. 2009. Manajemen Sumber Daya Manusia Untuk Perusahaan. Jakarta : Rajawali Pers.

Siagian, Sondang P., 2009. Kiat Meningkatkan Produktifitas Kerja. Jakarta : Rineka Cipta.

Sudarman, D. 2004. Motivasi Kepemimpinan dan Efektivitas Kelompok. Jakarta : Rineka Cipta.

Umar Husein. 2013. Metode Penelitian. Jakarta : Rajawali.

Wibowo. 2012. Manajemen Kinerja Edisi Ketiga. Jakarta: Rajawali Pers. 